\title{
Efficient Synthesis of a Highly Active Catalyst for $\mathrm{CO}_{2} /$ Epoxide Copolymerization
}

\author{
Jaelj Min, Jong Eon Seong, Sung Jae Na, Anish Cyriac, and Bun Yeoul Lee` \\ Department of Molecular Science and Technologv. Ajou Chiversitw, Suwon 4+3-749, Korea \\ -E-mail: bumveoula ajou ackr \\ Received January 8. 2009. Accepted February 4, 2009
}

Key Words: Carbon dioxide. Epoxide. Salen-cobalt complexes, Quaternary anmonium salt, Polymerization

The carbon dioxide/propylene oxide $\left(\mathrm{CO}_{-} / \mathrm{PO}\right)$ copolymer is attractive in many aspects and so has attracted much interest. ${ }^{1}$ The copolymer. which consists of alternating $\mathrm{CO}_{2}$ and $\mathrm{PO}$ subunits. has $4+\%$ by weight $\mathrm{CO}_{2}$. The $\mathrm{CO}_{2}$ gas is abundant and cheap. making the copolymer economical to prepare. The copolymer burns gently in air without enission of toxic materials. decomposes at a relatively low temperature of approximately $250^{\circ} \mathrm{C}$ without an ash residue, and adheres strongly to a cellulosic substrate. These merits have been blunted by the lack of commercial quantities of the polymer due to the absence of a satisfactory catalytic system. We recently reported a highly active catalyst (1) that has the potential to be applied in a commercial process (equation 1 ). ${ }^{2} \mathrm{~A}$ key to the catalyst is the binding of two components-Salen-cobalt(III) unit and quaternary' ammonium salt-in proximity regardless of either low catalyst concentration or high polymerization temperature. which consequently allows a high turnover number (TON) and a ligh molecular weight $\left(\mathrm{M}_{\mathrm{n}}\right)$ of the resulting polymer. With the conventional binary sy'stems of [( $\mathrm{Salen}) \mathrm{Co}^{3}$ or ( $\left.\mathrm{Salen}\right) \mathrm{Cr}$ comple. $\left.{ }^{-4}\right]$ /(onium salt or base), where the two components are not bound, catalytic performance is not observed at a low catalyst concentration and/or high poly merization temperature. Thus. a high TON and a high molecular weight could not be attained. Using the compound detailed in 1 a TON exceeding 20.000 and turnover frequency (TOF) more than $20,000 \mathrm{~h}^{-1}$ were achieved and a strictly alternating copoly mer of a high $\mathrm{M}_{\mathrm{n}}$ up to 300,000 was provided with a high selectivity ( $>99 \%$ ). The
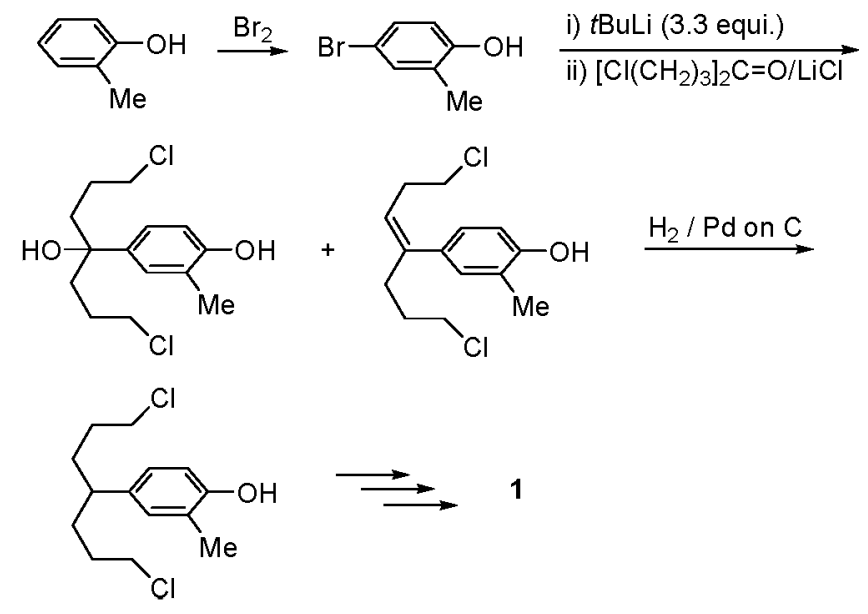

2

Scheme 1. Synthetic Route for a Highly Active Catalyst for $\mathrm{CO}_{2} / \mathrm{PO}$ Copolymerization highly active catalyst 1 was prepared through a rather lengthy synthetic route (Scheme 1). which might be a bottleneck for commercial utilization of the catalyst. In this work, we report a shortened synthetic route.

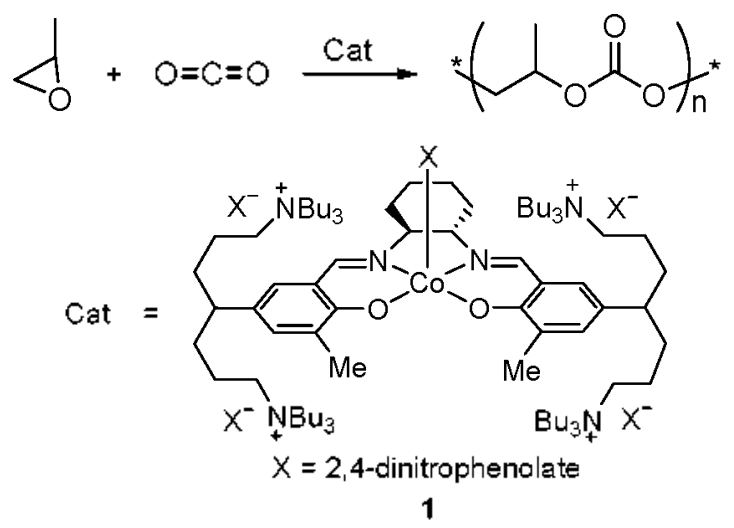

In the previous synthetic route. there were problems in the early steps to prepare a key internediate 2 from ortho-cresol (Scheme 1). A para-regioselective bromination of $o$-cresol was reported in $96 \%$ isolated yield using $N$-bromosuccinimide (NBS). ${ }^{5}$ The product was isolated from a side product of succinimide by column chronatograply using silica gel, which hampers scale-up of this step. When $\mathrm{Br}_{2}$ was employed instead of NBS. some side reactions such as benzylic bromination or dibromination, were conconitant and the yield was lowered to $80 \%$. To remove the side products. the crude product should also be purified by colunn chromatography using silica gel. We experienced a more severe problem in the second step of Scheme 1 . We added 3.3 equivalents of $t \cdot \mathrm{BuLi}$ under an inert atmosphere using a rigorously dried solvent at a low temperature $\left(-78^{\circ} \mathrm{C}\right)$. The product was a mixture of a benzylic tertiary-alcohol and its $\mathrm{H}_{2} \mathrm{O}$-eliminated alkene compound contaminated with some $o$-cresol. $o$-Cresol might be generated through deprotonation of the $\alpha$-proton in 1,7-dichloro-theptanone by the action of the lithiated compound. This protonation side reaction was inevitable even though we added $\mathrm{LiCl}$ in the reaction to facilitate carbonyl attack. ${ }^{\circ}$ The mixture of products was isolated through an exhaustive silica gel column chromatography. Hydrogenation of the mixture of terticiry-alcohol and alkene produced the desired compound (2) in fairly good yield, but the crude product should also be purified by silica gel colunn chromatography. The overall yield from 3-bromo-2-methylphenol to 2 moderately fluctuated from batch-by-batch (52-67\%). In subsequent steps from 2 to 
reach the target complex 1 , we did not have any significant problems: the yield for each step was almost quantitative and the product for each step could be used for the subsequent next step without the need of extensive purification.

We developed a very simple route that attaches $-\mathrm{CMe}\left[\left(\mathrm{CH}_{2}\right)_{3-}\right.$ $\mathrm{Cl}]_{2}$, instead of $-\mathrm{CH}\left[\left(\mathrm{CH}_{2}\right)_{3} \mathrm{Cl}\right]_{2}$ in 2, at the para-position of $o$-cresol (equation 2). Thus. Friedel-Craft alkylation of $o$-cresol using 1.7-dichloro-4-methylheptan-4-ol (3) in the presence of $\mathrm{AlCl}_{3}$ produced the desired compound 4 in $97 \%$ yield. In this reaction. $o$-cresol was used as both a reactant and a solvent. and no additional solvent was required. The excess $o-c r e s o l$ was recovered by vacuum distillation $\left(45^{\circ} \mathrm{C} / 2 \mathrm{mmHg}\right)$ and the remaining residue was pure 4 as determined by ${ }^{1} \mathrm{H}$ and ${ }^{13} \mathrm{C}\left\{{ }^{\mathrm{l}} \mathrm{H}\right\}$ NMR, and was amenable for the next reaction without further purification. We could prepare 4 in a $25 \mathrm{~g}$ scale with a $250 \mathrm{~mL}$ scale glassware. The reactant 3, 1.7-dichloro-4-methylheptan$4-0 l$. was prepared in $95 \%$ yield through MeLi treatment of 1.7-dichloro-4-heptanone. which can be easily prepared using inexpensive $\gamma$-buttrolactone in large scale in one-step reaction. The MeLi addition reaction is also very clean. yielding a crude product that can be used without further purification in the Friedel-Craft alkỵlation reaction.

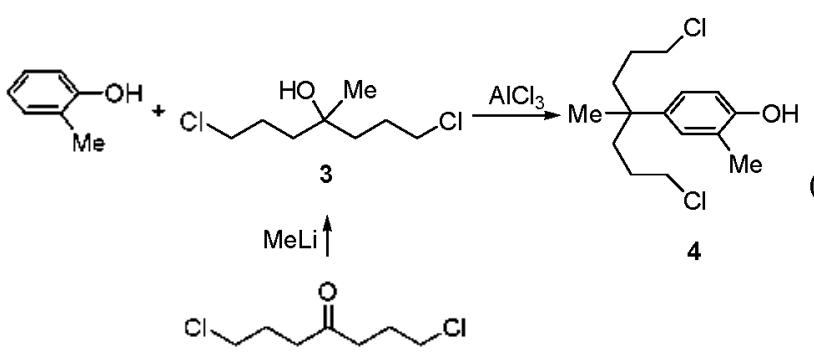

Starting from 4 we prepared the corresponding Salencobalt(III) complex (Scheme 2). Formylation of + using paraformaldehyde. triethỵlamine, and magnesium cluloride yielded 5 with good efficiency. ${ }^{8}$ Because tributylanine cannot attack chloroalkane. the chloro-group is transformed into a more reactive iodo-group. The yield for this step was almost quantitative, but at this stage the product needs to be purified by passage through a short pad of silica gel. Formation of a quatemary ammonium salt at this salicylaldelyde stage is unsatisfactory. An accompanying side reaction occurred, which night represent an attack of the phenolate anion generated by the action of tributylamine base on phenolic proton, onto the iodo-group. When formation of the quatemary ammonium salt was carried out after the formation of Salen-type ligand 7 , the side reaction was negligible and formation of the desired conpound occurred in a near quantitative yield. Because iodide anion intervenes in the metallation reaction, it was replaced with an inert $\mathrm{BF}_{4}^{-}$through the treatment of $\mathrm{AgBF}_{4}$. Metallation was carried out by a routine method involving the treatment of $\mathrm{Co}(\mathrm{OAc})_{2}$ in ethanol and oxidation using $\mathrm{O}_{2}$ in the presence of an equivalent amount of 2.4-dinitrophenol. Finally. the inert $\mathrm{BF}_{4}^{-}$was replaced with an active 2,4-dinitrophenolate anion by stirring the solution of cobalt complex over a slurry of excess sodium 2.4-dinitrophenolate in $\mathrm{CH}_{2} \mathrm{Cl}_{2} .{ }^{1} \mathrm{H}$ and ${ }^{13} \mathrm{C}\left\{{ }_{\{}^{1} \mathrm{H}\right\}$ NMR spectra signals produced by conplex 10 were broad at room temperature, but became sharp enough to be assignable by raising the temperature. Complex 10 also displayed excellent polymerization performance for $\mathrm{CO}_{3} / \mathrm{PO}$ copolymerization at the conditions of $[\mathrm{PO}] /[\mathrm{Cat}]=50000,80^{\circ} \mathrm{C}$. and $\mathrm{CO}_{2}$ pressure $=$ 2.0-1.7 MPa (TON, 6200: TOF. $9200 \mathrm{~h}^{.}$, the selectivity for the formation of polymer over the cyclic carbonate of $96 \%$ : $\mathrm{M}_{\mathrm{rl}}$ of the obatined polymer of 89000 ; molecular weight distribution $\left(\mathrm{M}_{\mathrm{w}} / \mathrm{M}_{\mathrm{n}}\right)$ of $\left.1.2 \mathrm{I}\right)$.

In sunmary. we developed a shortened synthetic route for a highly active catalyst for $\mathrm{CO}_{2} / \mathrm{PO}$ copolymerization. This route allows the scaleable synthesis of the potential catalyst. which will encourage the conmercialization of these $\mathrm{CO}_{2} / \mathrm{PO}$ copolymers

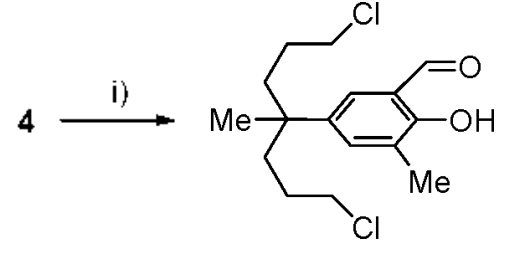

5

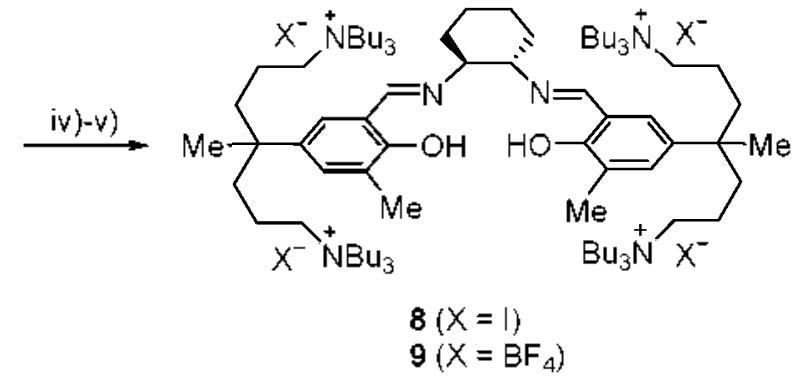

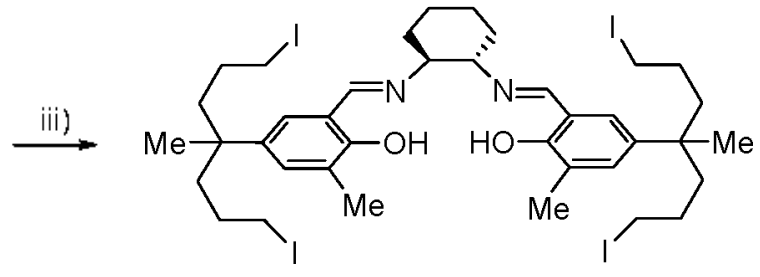

7

6

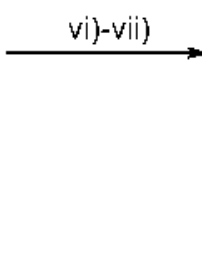

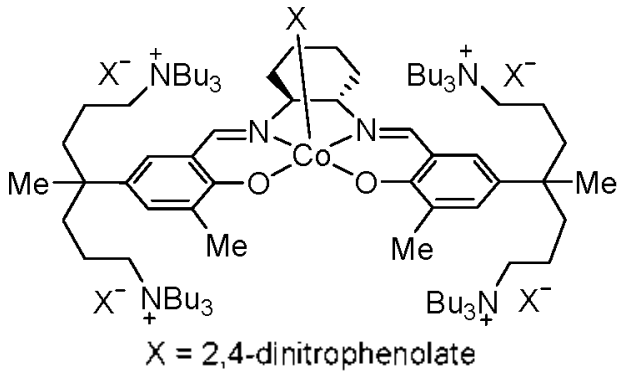

10

Scheme 2. i) Paraformaldehyde/ $\mathrm{NEt}_{3} / \mathrm{MgCl}_{2}$; ii) $\mathrm{NaI}$ in $\mathrm{CH}_{2} \mathrm{CN}$; iii) 1,2-Trons-diaminocyclohexane in $\mathrm{CH}_{2} \mathrm{Cl}_{2} ;$ iv) $\mathrm{Bu}_{3} \mathrm{~N}$ in $\mathrm{CH}_{3} \mathrm{CN}_{\text {; }}$ v) $\mathrm{AgBF}$; vi) $\mathrm{Co}(\mathrm{OAc})_{2}$ in ethanol; vii) $\mathrm{O}_{2}$ and 2,4 -dinitrophenol in $\mathrm{CH}_{2} \mathrm{Cl}_{2}$, then sodium 2,4-dinitrophenolate. 


\section{Experimentals}

Genemal remarks. All manipulations were performed under an inert atmosphere using standard glove box and Schlenk techniques. THF and diethỵl ether were distilled from benzophenone ketyl. Ethanol was dried as previously described using sodium and diethyl phthalate. ${ }^{9} \mathrm{CH}_{3} \mathrm{CN} . \mathrm{CH}_{2} \mathrm{Cl}_{3}$, and $\mathrm{CDCl}_{3}$ were dried by stiming over $\mathrm{CaH}_{2}$. and were subsequently vacuum-transferred to reservoirs. $o$-Cresol was dried over molecular sieves. 1.7-Dichloroheptan-4-one was prepared as previously described. $\mathrm{CO}_{2}$ gas (99.999\% purity) was dried by storing in a column of molecular sieves $3 \mathrm{~A}$ at a pressure of 30 bar. Propylene oxide ( $\mathrm{PO}$ ) was dried by stiming over $\mathrm{CaH}_{2}$ for several days and was vacuum-transferred to a reservoir. The ${ }^{1} \mathrm{H}$ NMR $(400 \mathrm{MHz})$ and ${ }^{13} \mathrm{C}\left\{{ }^{1} \mathrm{H}\right\}$ NMR $(100 \mathrm{MHz})$ spectra were recorded on a Varian Mercury Plus 400. Elemental analy ses were carried out at the Analytical Center. Kyunghee University. Mass spectral data were obtained from the Korea Basic Science Institute (Daegu) on a Jeol JMS 700 high resolution mass spectrometer. Gel permeation chromatograms (GPC) were obtained at room temperature in THF using a Waters Millennium apparatus with poly styrene standards.

Synthesis of 1,7-dichloro-4-methylheptan-4-0l (3). To a flask containing 1.7-dichloroheptan-4-one (17.40 g. 95.04 munol) in diethyl ether $(285 \mathrm{~mL})$ was added $\mathrm{MeLi}(81.0 \mathrm{~g} .1+3$ mmol. $1.5 \mathrm{M}$ in diethyl ether) dropwise at $-78{ }^{\circ} \mathrm{C}$ under nitrogen. After stirring at $-78^{\circ} \mathrm{C}$ for two hours. the reaction was quenched by addition of water $(170 \mathrm{~mL})$ at $-78^{\circ} \mathrm{C}$. The organic phase was collected and the water phase was further extracted with the addition of dietlyyl ether $(3 \times 300 \mathrm{~mL})$. After the combined diethyl ether was dried over anhy'drous $\mathrm{MgSO}_{4}$, the solvent was removed with a rotary evaporator to give an oily residue. which is used for the next reaction without further purification ( $18.0 \mathrm{~g} .95 \%)$. The compound slowly decomposed during storage and was used for the next step immediately following preparation. ${ }^{1} \mathrm{H} \mathrm{NMR}\left(\mathrm{CDCl}_{3}\right)$ : $\tilde{\delta}$ 3.59 (t. $\left.J=6.4 \mathrm{~Hz}, 4 \mathrm{H}, \mathrm{CH}_{2} \mathrm{Cl}\right) .1 .90-1.86\left(\mathrm{~m}, 4 \mathrm{H}, \mathrm{CH}_{2}\right)$. 1.65-1.61 (m. 4H. CH $) .1 .23$ (s. $\left.\left.3 \mathrm{H}, \mathrm{CH}_{3}\right) \mathrm{ppm} .{ }^{13} \mathrm{C}^{1}{ }^{1} \mathrm{H}\right\} \mathrm{NMR}$ $\left(\mathrm{CDCl}_{3}\right): \hat{o} 72.32,45.88 .39 .51,27.61 .27 .23 \mathrm{ppm}$

Synthesis of 4. 0 -Cresol (78.17 g. $722.8 \mathrm{mmol}), 1,7$-dichloro4-methy lheptan-4-ol (17.99 g. $90.35 \mathrm{mmol})$. and $\mathrm{AlCl}_{3}(13.25$ g. $99.39 \mathrm{mmol}$ ) were mixed and the mixture was stirred overnight under an atmosphere of $\mathrm{N}_{2}$. The reaction was quenched by the addition of diethyl ether $(500 \mathrm{~mL})$ and water $(300$ $\mathrm{mL}$ ). The organic phase was collected and the water phase was further extracted with additional diethyl ether $(3 \times 300$ $\mathrm{mL}$ ). After the combined diethyl ether was dried over anhydrous $\mathrm{MgSO}_{+}$the solvent was removed with a rotary evaporator. The excess $o$-cresol was recovered by vacuum distillation $\left(+5^{\circ} \mathrm{C} / 2 \mathrm{mmHg}\right) .{ }^{1} \mathrm{H}$ and ${ }^{13} \mathrm{C}$ NMR analysis indicated that the oily residue was pure enough to be used for the next reaction without further purification $(25.40$ g. $97 \%)$. IR (KBr): 3528 $(\mathrm{OH}) \mathrm{cm}^{-1} .{ }^{1} \mathrm{H} \mathrm{NMR}\left(\mathrm{CDCl}_{3}\right): 87.01(\mathrm{~d} J=2.0 \mathrm{~Hz} .1 \mathrm{H}, m-\mathrm{H})$, $6.97(\mathrm{dd}, J=8.0 \mathrm{~Hz}, 2.0 \mathrm{~Hz} .1 \mathrm{H}, m-\mathrm{H}) .6 .72(\mathrm{~d} . J=8.0 \mathrm{~Hz}, 1 \mathrm{H}$, $o-\mathrm{H}$ ). 4.85 (s. IH. OH) 3.45 (t. $J=6.4 \mathrm{~Hz}, 4 \mathrm{H} . \mathrm{CH}_{2} \mathrm{Cl}$ ) 2.27 (s, $\left.3 \mathrm{H}_{1} \mathrm{CH}_{3}\right), 1.86-1.44\left(\mathrm{~m}, 8 \mathrm{H}, \mathrm{CH}_{2}\right), 1.30$ (s. $\left.3 \mathrm{H} . \mathrm{CH}_{3}\right) \mathrm{ppm}$. ${ }^{13} \mathrm{C}\left\{{ }^{l} \mathrm{H}\right\} \mathrm{NMR}\left(\mathrm{CDCl}_{3}\right): \delta$ 151.79, 138.67. 129.06. 125.02 . $123.45,114.85,46.20,41.12,39.95,28.09,24.22$. $16.58 \mathrm{ppm}$.
HRMS (EI): $m z$ calcd $\left(\mathrm{M}^{+} \mathrm{C}_{15} \mathrm{H}_{22} \mathrm{Cl}=\mathrm{O}\right) 288.1046$, found 288.1048

Synthesis of 6. Conpound $4(25.40$ g. $87.83 \mathrm{mmol})$ was dissolved in anhydrous THF $(650 \mathrm{~mL})$. Paraformaldehyde (10.55 g. $351.3 \mathrm{mmol})$, triethylamine $(37.31 \mathrm{~g} .368 .9 \mathrm{mmol}$ ) and magnesium clloride ( $33.52 \mathrm{~g}, 351.3 \mathrm{mmol}$ ) were added under $\mathrm{a} \mathrm{N}_{2}$ atmosphere. The reaction misture was heated to reflux for 5 hours and cooled to room temperature. The solvent was removed with a rotary evaporator. Water ( 300 $\mathrm{mL})$ and $\mathrm{CH}_{2} \mathrm{Cl}_{2}(500 \mathrm{~mL})$ were added to the residue. and the mixture was filtered over Celite. The organic phase was collected. and the aqueous phase was further extracted using $\mathrm{CH}_{2} \mathrm{Cl}_{2}(2 \times 300 \mathrm{~mL})$. The combined organic plase was dried over anhydrous $\mathrm{MgSO}_{4}$. The solvent was removed with a rotary evaporator to give an oily residue that was evacuated further to remove some residual triethylanine. The residue was dissolved in $\mathrm{CH}_{3} \mathrm{CN}(110 \mathrm{~mL})$ and $\mathrm{NaI}(126.4 \mathrm{~g} .843 .2$ mmol) was added. After the resulting nuxture was refluxed for 20 hours. it was cooled to room temperature. After water $(300 \mathrm{~mL})$ was added, the product was extracted using diethyl ether $(3 \times 300 \mathrm{~mL})$. After the collected organic phase was dried over anhydrous $\mathrm{MgSO}_{4}$, all volatiles were removed with a rotary evaporator to give a yellow oil. The product was purified by column chromatography on silica gel. eluting with hexane and toluene (v/v: $5: 1)$. The yield was $83 \%(22.2 \mathrm{~g})$. IR $(\mathrm{KBr}): 3448(\mathrm{OH}), 1650(\mathrm{C}=\mathrm{O}) \mathrm{cm}^{-1} .{ }^{1} \mathrm{H}$ NMR $\left(\mathrm{CDCl}_{3}\right): \hat{\delta}$ $11.14(\mathrm{~s}, 1 \mathrm{H} . \mathrm{OH}) .9 .87(\mathrm{~s}, 1 \mathrm{H}, \mathrm{CH}=\mathrm{O}), 7.33(\mathrm{~d} . J=2.4 \mathrm{~Hz}$, lH. $m-\mathrm{H}), 7.25$ (d. $J=2 .+\mathrm{Hz} .1 \mathrm{H} . m-\mathrm{H}) .3 .14-3.09(\mathrm{~m}, 4 \mathrm{H}$. $\mathrm{CH}_{2} \mathrm{I}$ ). 2.30 (s. $3 \mathrm{H}_{2} \mathrm{CH}_{3}$ ). $1.87-1.43$ (m. $8 \mathrm{H}, \mathrm{CH}_{2}$ ). 1.34 (s. $3 \mathrm{H}$. $\left.\mathrm{CH}_{3}\right)$ ppm. ${ }^{13} \mathrm{C}\left\{{ }^{1} \mathrm{H}\right\} \mathrm{NMR}\left(\mathrm{CDCl}_{3}\right): \delta 196.85 .158 .20,137.51$. $136.09 .128 .85,126.93,119.62 .44 .28,39.95,28.66,24.16$. $15.81,7.99$ ppm. Anal. Calcd. $\left(\mathrm{C}_{16} \mathrm{H}_{22} \mathrm{I}_{2} \mathrm{O}_{2}\right): \mathrm{C}, 38.42: \mathrm{H}, 4.43$ $\%$. Found: C. 38.46: H, $4.24 \%$.

Synthesis of 7. Compound 6 (20.67 g. $41.33 \mathrm{mmol})$ and $( \pm)$-trans-1.2-dianunocyclohexane $(2.360$ g. $20.66 \mathrm{mmnol})$ were weighed into a one-neck flask. and then $\mathrm{CH}_{2} \mathrm{Cl}_{2}(240$ $\mathrm{mL}$ ) was added. The solution was stirred overnight under a $\mathrm{N}_{2}$ atmosphere. The solvent was removed under vacuum to give a pure compound $(21.84 \mathrm{~g}$. $98 \%$ ). IR $(\mathrm{KBr}): 3432(\mathrm{OH}), 1629$ $(\mathrm{C}=\mathrm{N}) \mathrm{cm}^{-1} .{ }^{1} \mathrm{H} \mathrm{NMR}\left(\mathrm{CDCl}_{\mathrm{s}}\right): \hat{o} 13.44$ (s. $\left.2 \mathrm{H} . \mathrm{OH}\right), 8.31$ (s, $2 \mathrm{H} . \mathrm{CH}=\mathrm{N}) .7 .04(\mathrm{~d}, J=1.6 \mathrm{~Hz}, 2 \mathrm{H} . m-\mathrm{H}) .6 .9 \mathrm{l}(\mathrm{d} . J=1.6 \mathrm{~Hz}$. 2H. $m-\mathrm{H})$. 3.38-3.35 (m, 2H, cyclohexyl-CH), 3.08-3.03 (m, $\left.8 \mathrm{H} . \mathrm{CH}_{2} \mathrm{I}\right) .2 .25$ (s. 3H. $\mathrm{CH}_{3}$ ). 1.96-1.89 (m. H. cyclohexyl- $\left.\mathrm{CH}_{2}\right)$. 1.96-1.43 (m. $20 \mathrm{H}$. cyclohexyl- $\mathrm{CH}_{2}$ and $\left.\mathrm{CH}_{2}\right) .1 .26$ (s. $6 \mathrm{H}$, $\left.\mathrm{CH}_{3}\right) \mathrm{ppm} .{ }^{13} \mathrm{C}\left\{{ }^{1} \mathrm{H}\right\} \mathrm{NMR}\left(\mathrm{CDCl}_{3}\right): 0$ oे. 165.01. 157.31, 136.12. $131.35 .126 .93,125.54,117.67,72.94,44.47,39.79,33.73$, $28.72,24.57,24.32$. 16.28. 8.38. $8.26 \mathrm{ppm}$. Anal. Calcd. $\left(\mathrm{C}_{38} \mathrm{H}_{54} \mathrm{I}_{4} \mathrm{~N}_{2} \mathrm{O}_{2}\right):$ C. 42.32 : H. 5.05: N. 2.60\%. Found: $\mathrm{C}$. 42.63: H, 5.21: N. $2.41 \%$.

Synthesis of 8. Compound 7 (21.08 g. $19.55 \mathrm{mmol})$ and tributylamine $(15.22 \mathrm{~g} .82 .10 \mathrm{mmol})$ were weighed into a one-neck flask, and $\mathrm{CH}_{3} \mathrm{CN}(210 \mathrm{~mL})$ was added. The solution was refluxed for 2 days under a $\mathrm{N}_{2}$ atmosphere. After the solution was cooled to room temperature. the solvent was removed under vacuum to give a residue that was subsequently triturated three times in diethyl ether $(20 \mathrm{~mL})$ to give a light yellow powder in $96 \%$ yield ( $34.13 \mathrm{~g} .18 .76 \mathrm{mmol})$. IR ( $\mathrm{KBr}$ ): $3+13(\mathrm{OH}), 1627(\mathrm{C}=\mathrm{N}) \mathrm{cm}^{-1} .{ }^{1} \mathrm{H}$ NMR $\left(\mathrm{CDCl}_{3}\right): \mathbf{8} .13 .50(\mathrm{~s}$. 
$2 \mathrm{H} . \mathrm{OH}) .8 .52(\mathrm{~s}, 2 \mathrm{H} . \mathrm{CH}=\mathrm{N}), 7.25$ (s. $2 \mathrm{H}, m-\mathrm{H}), 7.2+$ (s. $2 \mathrm{H}$, $m-\mathrm{H}$ ) 3.53 (br. $2 \mathrm{H}$. cyclohexyl-CH) 3.27 (br. $32 \mathrm{H}, \mathrm{NCH}_{2}$ ). 2.23 (s. $6 \mathrm{H}, \mathrm{CH}_{3}$ ), 1.93-1.80 (br, $4 \mathrm{H}$. cyclohexyl- $\mathrm{CH}_{2}$ ). $1.57-1.33$ (br, $74 \mathrm{H}), 0.91-0.88$ (t. $\left.36 \mathrm{H} . \mathrm{CH}_{3}\right)$ ppm. ${ }^{13} \mathrm{C}\{\mathrm{H}\}$ NMR $\left(\mathrm{CDCl}_{3}\right): \dot{0} .164 .72,157.54,135.30,131.09,127.10$. 125.46. 117.62. 71.96. 59.88, 59.02. 40.27. 37.81, 37.56. $25.87,25.78,24.26,23.92,19.81,18.30 .15 .97,13.84 \mathrm{ppm}$. Anal. Calcd. $\left(\mathrm{C}_{86} \mathrm{H}_{16} \mathrm{~B}_{4} \mathrm{~F}_{16} \mathrm{~N}_{6} \mathrm{O}_{2}\right)$ : C. $56.76:$ H. 8.97; N. 4.62 $\%$. Found: C. $56.86:$ H. $9.13:$ N. $4.65 \%$.

Synthesis of 9 . To a flask containing $8(5.0 \mathrm{~g} .2 .75 \mathrm{mmol})$ and $\mathrm{AgBF}_{4}(2.1+\mathrm{g}, 11 \mathrm{mmol}) . \mathrm{CH}_{2} \mathrm{Cl}_{2}(50 \mathrm{~mL})$ was added rapidly with stirring. Black precipitates were observed as soon as ethanol was added and stirring was ceased due to the formation of a lump of light yellow solid. The lump was broken down with a spatula to facilitate the stiming. The solution was stirred for a day in the dark. After the generated AgI was filtered off over Celite inside a glove box, the solvent was immediately removed under vacuum to give a residue that was redissolved in $\mathrm{CH}_{2} \mathrm{Cl}_{2}(\sim 6 \mathrm{~mL})$. The solution was filtered again over Celite, and the solvent was removed under vacuum to yield a yellow residue that was subsequently purified by column chromatography on a short pad of silica gel. eluting with ethanol and $\mathrm{CH}_{2} \mathrm{Cl}_{2}(\mathrm{~F} / \mathrm{v}, \mathrm{l}: 5)$. The yield was $3.25 \mathrm{~g}(71 \%)$. $\mathbb{R}(\mathrm{KBr}): 3413(\mathrm{OH}) .1627(\mathrm{C}=\mathrm{N}) \mathrm{cm}^{-1} \cdot{ }^{1} \mathrm{H}$ NMR $\left(\mathrm{CDCl}_{3}\right)$ : ô. 13.55 (5. $\left.2 \mathrm{H}, \mathrm{OH}\right) .8 .42$ (s. $\left.2 \mathrm{H} . \mathrm{CH}=\mathrm{N}\right)$. 7.12 (s. $2 \mathrm{H}, m-\mathrm{H}) .7 .08$ (s. $2 \mathrm{H} . m-\mathrm{H}) .3 .38$ (br. $2 \mathrm{H}$. cyclohesyl$\mathrm{CH}), 3.06$ (br. $\left.32 \mathrm{H}, \mathrm{NCH}_{2}\right) .2 .20\left(\mathrm{~s}, 6 \mathrm{H}, \mathrm{CH}_{3}\right) .1 .88-1.84$ (br. 4 H. cyclohexyl-CH: $1.68-1.26$ (br. $74 \mathrm{H}$ ), 0.87-0.86 (br. $\left.36 \mathrm{H}, \mathrm{CH}_{3}\right)$ ppm. ${ }^{13} \mathrm{C}\{\mathrm{H}\}$ NMR $\left(\mathrm{CDCl}_{3}\right): \delta .165 .23,157.79$. $135.21 .131 .17,127.18 .125 .76 .117 .91,72.05 .59 .17 .58 .63$, $40.16,38.10 .37 .71,26.45,24.91 .23 .90,20.31$. 19.80, 17.30. 16.01. 13.97, 13.80, 13.79 ppm Anal. Calcd. $\left(\mathrm{C}_{86} \mathrm{H}_{16} \mathrm{~B}_{4} \mathrm{~F}_{16} \mathrm{~N}_{6} \mathrm{O}_{2}\right)$ : C. $62.24:$ H. 9.84: N. $5.06 \%$. Found: C. $62.03:$ H. 10.00: N. $5.15 \%$.

Synthesis of 10 . Cobalt(II) acetate $(0.221 \mathrm{~g}, 1.247 \mathrm{mmol})$ and ligand $9(2.07 \mathrm{~g} .1 .247 \mathrm{mmol})$ were dissolved in ethanol $(50 \mathrm{~mL})$ inside a glove box. The solid precipitated in approximately 5 minutes. The resulting slurry was stirred for 3.0 hours at room temperature. The solvent was removed under vacuum to give a red solid that was subsequently triturated two times in diethyl ether $(30 \mathrm{~mL})$ to remove acetic acid that had been generated. The solid was dissolved in $\mathrm{CH}_{2} \mathrm{Cl}_{2}(50$ $\mathrm{mL}$ ) containing 2.4-dinitrophenol (0.229 g. $1.247 \mathrm{mmol})$, and the solution was stirred under an $\mathrm{O}_{2}$ atmosphere for 3 hours. Sodium-2.4-dinitrophenolate ( $1.28 \mathrm{~g} .6 .21 \mathrm{mmol}$ ) was added. After the solution was stirred overnight at room temperature. it was filtered over Celite. The solvent was removed under vacuum to give a dark brown powder that was pure enough to be used for polymerization. Yields were quantitative $(2.84 \mathrm{~g})$. ${ }^{1} \mathrm{H}$ NMR (DMSO-d $\left.38^{\circ} \mathrm{C}\right): \hat{\delta} .8 .65$ (br. $\left.4 \mathrm{H}_{.}\left(\mathrm{NO}_{2}\right)_{2} \mathrm{C}_{6} \mathrm{H}_{3} \mathrm{O}\right), \hat{o}$. $7.88\left(\mathrm{br}, 6 \mathrm{H},\left(\mathrm{NO}_{2}\right)_{2} \mathrm{C}_{6} \mathrm{H}_{3} \mathrm{O}, \mathrm{CH}=\mathrm{N}\right), 7.31$ (br. $\left.4 \mathrm{H} . m-\mathrm{H}\right), 6.39$ (br. $\left.4 \mathrm{H} .\left(\mathrm{NO}_{2}\right)_{2} \mathrm{C}_{6} \mathrm{H}_{3} \mathrm{O}\right), 3.38$ (br, $2 \mathrm{H}$. cyclohexyl-CH). 3.08 (br, $\left.32 \mathrm{H}, \mathrm{NCH}_{2}\right), 2.64$ (s. $6 \mathrm{H}, \mathrm{CH}_{3}$ ), $2.06-1.85$ (br, $4 \mathrm{H}$. cyclohexyl- $\mathrm{CH}_{2}$ ). 1.50-1.15 (br. $74 \mathrm{H}$ ), 0.86 (br, $36 \mathrm{H}, \mathrm{CH}_{3}$ ) ppm.

$\mathrm{CO}_{2} / \mathrm{PO}$ copolymerization. Into a bomb reactor $(50 \mathrm{~mL})$. inside a glove box. the complex $(8.0 \mathrm{mg}$ for $[\mathrm{PO}] /[\mathrm{Cat}]=$ $50000)$ and propylene oxide ( $10.0 \mathrm{~g} .172 \mathrm{mmol}$ ) were added. The bomb reactor was assembled and immersed in an $80^{\circ} \mathrm{C}$ oil bath. It was stirred for 15 minutes to allow the solution temperature to reach the bath temperature. $\mathrm{The}^{\mathrm{CO}_{2}}$ gas was pressurized to 20 bar and the valve was closed. Thirty nunutes later. a pressure drop started. indicating commencement of polymerization. The $\mathrm{CO}_{2}$ valve was opened and $\mathrm{CO}_{2}$ was continuously fed for 1 hours. The reactor was cooled to room temperature by immersion in an ice bath. After the $\mathrm{CO}_{2}$ gas was released. the reactor was opened. An aliquot was taken and dissolved in $\mathrm{CDCl}_{2}{ }^{1} \mathrm{H}$ NMR analy sis of the solution indicated that the the selectivity for the formation of polymer over the cyclic carbonate is $96 \%$ and a strictly altemating copolymer was formed. The viscous solution was diluted with $10.0 \mathrm{~g}$ of PO and the viscous solution was filtered over a short pad of silica gel to give a colorless solution. Volatiles were removed using a rotary evaporator to give a white residue. The poly mer lump was taken out of the flask and then broken manually to pieces. After the poly mer pieces were placed in a hood overnight to evaporate some residual PO. they were completely dried in an oven at approximately $150{ }^{\circ} \mathrm{C}$ for 30 minutes. The yield was $2.15 \mathrm{~g}\left(\mathrm{TON}=6100: \mathrm{TOF}=9200 \mathrm{~h}^{-3}\right.$ excluding induction time). Averaged molecular weight $\left(\mathrm{M}_{\mathrm{n}}\right)$ and molecular weight distribution $\left(\mathrm{M}_{w} / \mathrm{M}_{1}\right)$ measured on GPC and calculated based on polỵsțrene standard were 89000 and 1.21 , respectively.

Acknowledgments. This research was supported by a grant from Construction Teclunology Innovation Program (CTIP) funded by Ministry of Land. Transportation and Maritime Affairs (MLTM) of Korean government.

\section{Refeiences}

1. (a) Darensbourg, D. J. Chem. Rev. 2007, 107, 2388, b) Coates, G. W. Moore, D. R. Angew'. Chent. Int. Ed. 2004, 43,6618.

2. (a) S, S.; Min, J. K ; Seong, J. E; Na, S. J; Lee, B. Y. Angew: Chem. Int Ed. 2008, 47, 7306 (b) Noh, E. K.: Na, S. J.: S, S.; Kim, S.W.; Lee, B. Y. J. Am. Chem. Soc. 2007, 129, 8082

3. (a) Lu, X.-B.; Shi, L.; Wang, Y.-M.; Zhang, R.; Zhang, Y.-T:Peng, X.-T.; Zhang, Z.-C.; Li, B. J. Ant Chent. Soc. 2006, 128, 1664. (b) Cohen, C. T. Thomas, C. M. Peretti, K. L. Lobkossky, E. B. Coates, G. W. Dalton Trans. 2006, 237. (c) Paddock, R. L. Nguven, S. T. Macrontolecules 2005, 38,6251 .

4. (a) Darenshourg, D. J.; Phelps, A. L.; Gall, N. L.; Jia, L. Acc. Chem. Res. 2004, 37, 836. (b) Darensbours. D. T.; Mackiewicz, R. M. J. Am. Chem. Soc. 2005, 127, $14(226$.

5. Das, B. Venkateswarlu, K. Majhi, A. Siddaiah, V. Reddy, K. R. J. Mol. Catal A: Chem. 2007, 267,30.

6. (a) Wu, C. J.: Lee, S. H:; Yu, S. T.; Na, S. J: Yun, H.: Lee, B. Y. Organometallics 2008, 27, 3907. (b) Krasovskiy, A.: Kopp, F.; Knochel, P. Angew. Chent. Int. Ed. 2006, $45,497$.

7. Curtis, O. M. Ir; Sandri, J. M.; Crocker, R. E.; Hart, H. Org. Sinth. Coll. Iol. $H^{-}, 278$.

8. Hansen, T. V.: Skattebol, L. Tetrahedron Lett. 2005, $46,3829$.

9. Amarego, W. L. F.: Perrin, D. D. Purification of Laboratony Chemicals, $4^{\text {th }}$ ed; Butterworth-Heinemant: Singapore, 1996; $\mathrm{p}$ 209 